\title{
Lactose intolerance and risk of lung, breast and ovarian cancers: aetiological clues from a population-based study in Sweden
}

\author{
$\mathrm{J} \mathrm{Ji}^{*, 1}$, J Sundquist ${ }^{1,2}$ and $\mathrm{K}$ Sundquist ${ }^{1,2}$ \\ ${ }^{1}$ Center for Primary Health Care Research, Lund University, Malmö, Sweden and ${ }^{2}$ Stanford Prevention Research Center, Stanford \\ University School of Medicine, Stanford, CA, USA
}

Background: Individuals with lactose intolerance are recommended to avoid milk or dairy products, which may affect the development of cancer.

Methods: We identified individuals with lactose intolerance from several Swedish Registers linked to the Swedish Cancer Registry to calculate standardised incidence ratios (SIRs) for cancers in the breast, lung, and ovary.

Results: A total of 22788 individuals with lactose intolerance were identified, and their risks of lung $(S I R=0.55)$, breast $(S I R=0.79)$, and ovarian $(S I R=0.61)$ cancers were significantly decreased. Cancer incidences in the siblings and parents of individuals with lactose intolerance were similar to those in the general population.

Conclusions: In this large cohort study, people with lactose intolerance, characterised by low consumption of milk and other dairy products, had decreased risks of lung, breast, and ovarian cancers, but the decreased risks were not found in their family members, suggesting that the protective effects against these cancers may be related to their specific dietary pattern.

Lactose intolerance is a pathological condition characterised by abdominal symptoms caused by lactase deficiency (Vesa et al, 2000; Wilt et al, 2010). Lactose intolerance is an autosomal recessive condition related to two polymorphisms in the MCM6 gene (Enattah et al, 2002). The lowest reported prevalence is $2 \%$ in Scandinavia, whereas the prevalence in South America, Africa, and Asia is around $50 \%$, increasing to $100 \%$ in some Asian countries (Sahi, 1994). Lactose-intolerant individuals can consume small amount of dairy products (yoghurt and cheese), or use enzyme substitutes (Wilt et al, 2010), but they are usually recommended to avoid dairy products. Lactose intolerance should not be mixed up with lactose malabsorption that is not a pathological condition but a normal human phenotype.

A previous study that examined the per capita milk consumption among 27 countries found that it was positively associated with ovarian cancer risk (Cramer, 1989); however, subsequent epidemiological studies gave inconsistent results (Larsson et al, 2004; Genkinger et al, 2006; Larsson et al, 2006). In addition, the associations of dairy products with breast (Boyd et al, 1993; Missmer et al, 2002; Moorman and Terry, 2004; Dong et al, 2011) and lung cancers (Axelsson and Rylander, 2002) (Kubik et al, 2004; van der Pols et al, 2007) were also inconclusive. A recent review by the World Cancer Research Fund and American Institute of Cancer Research claimed no sufficient evidence to establish associations between dairy intake and breast cancer risk (World Cancer Research Fund, 2007). Measurement error may partly explain these inconclusive data because most studies defined dairy consumption using questionnaires. All the previous studies examined cancer risks among those with high consumption of dairy products, using those with low consumption as the reference group. Here, we examined this association by an alternative approach: determining whether low consumption of dairy products in individuals with lactose intolerance can protect against the development of these cancers. This study could be regarded as an application of Mendelian randomisation to epidemiology (Qi, 2009). In addition, we examined the risk of cancer in the 
first-degree relatives (siblings and parents) of individuals with lactose intolerance to exclude potential confounding factors, which cannot be measured.

\section{METHODS}

Individuals with lactose intolerance were identified from four Swedish Registers: the Primary Health Care Registers covering the counties of Skåne (1987-2010) and Stockholm (2001-2007) and the national Swedish Hospital Discharge Register (1987-2010) and Outpatient Register (2001-2010). The Primary Health Care Register in Region Skåne, PaSIS, contains data on all individuals (around 1.2 million) living in Skåne and who visited primary health care between 1987 and 2010. The Primary Health Care Register in Stockholm covers 75 primary health care centres for the period 2001-2007. The Swedish Hospital Discharge Register was founded in 1964-1965 by the National Board of Health and Welfare, and it has had complete nationwide coverage since 1987. The Outpatient Register contains data on all visits to outpatient clinics in Sweden since 2001. Individuals with lactose intolerance were identified according to the International Classification of Diseases (ICD-9 code 271D and ICD-10 code E73). Individuals with secondary lactose intolerance (ICD-10 code E731) were excluded from the study.

We further linked the individuals with lactose intolerance to the Swedish Cancer Registry to identify all incident cases of cancer during the study period. The Swedish Cancer Registry was founded in 1958 and has close to $100 \%$ coverage at the present time (Ji and Hemminki, 2007). All linkages were performed using individual national identification numbers, which were replaced with serial numbers in order to preserve anonymity. We identified the siblings and parents of individuals with lactose intolerance from the Swedish Multi-Generation Register (Ekbom, 2011), which contains data on the biological parents of index persons registered in Sweden since 1961 and born in or since 1932.

We calculated person-years at risk among individuals with lactose intolerance from the date of birth, immigration, or 1 January 1961, whichever came last, until the date of diagnosis of cancer, death, emigration, or the end of the study period (31 December 2010), whichever came first. Standardised incidence ratios (SIRs) were calculated as the ratio of the observed and expected number of cases (Breslow and Day, 1987; Rothman and Greenland, 1998). The expected number of cases was calculated by using the population incidence rate for all individuals without lactose intolerance. Standardised incidence ratios were standardised by 5 -year age group, sex (male and female), 5-year time period, and country of birth (Sweden, other European countries, and other countries) (Esteve et al, 1994). When calculating the SIRs for breast and ovarian cancers, additional adjustments were made for number of offspring (zero, one, two, and three or more) and age at first childbirth $(<25,25-34$, and $35+$ years $)$. Confidence intervals $(95 \%)$ for the SIRs were calculated assuming a Poisson distribution, and were rounded to the nearest two decimals (Esteve et al, 1994). All analyses were performed using SAS version 9.1 (SAS Institute, Cary, NC, USA).

\section{RESULTS}

In Table 1, we present the basic characteristics of individuals with lactose intolerance and their first-degree relatives. A total of 22788 individuals were identified with lactose intolerance in Sweden between 1987 and 2010. More women than men had lactose intolerance and the median age at diagnosis was 12 years. Most of the individuals with lactose intolerance (85\%) were born in
Table 1. Basic characteristics of individuals in Sweden with lactose intolerance and their first-degree relatives

\begin{tabular}{|c|c|c|c|c|c|c|}
\hline & \multicolumn{6}{|c|}{ First-degree relatives } \\
\hline & \multicolumn{2}{|c|}{$\begin{array}{c}\text { Lactose } \\
\text { intolerance }\end{array}$} & \multicolumn{2}{|c|}{ Siblings } & \multicolumn{2}{|c|}{ Parents } \\
\hline & No. & $\%$ & No. & $\%$ & No. & $\%$ \\
\hline \multicolumn{7}{|l|}{ Sex } \\
\hline Male & 9468 & 41.5 & 16602 & 50.6 & 18323 & 49.4 \\
\hline Female & 13320 & 58.5 & 16214 & 49.4 & 18783 & 50.6 \\
\hline \multicolumn{7}{|l|}{ Year of birth } \\
\hline Before 1950 & 2445 & 10.7 & 1934 & 5.9 & 7523 & 20.3 \\
\hline 1950-1959 & 1100 & 4.8 & 1349 & 4.1 & 6543 & 17.6 \\
\hline 1960-1969 & 1327 & 5.8 & 1682 & 5.1 & 13220 & 35.6 \\
\hline 1970-1979 & 1726 & 7.6 & 2912 & 8.9 & 8774 & 23.6 \\
\hline 1980-1989 & 3190 & 14.0 & 6666 & 20.3 & 1045 & 2.8 \\
\hline 1990-1999 & 7687 & 33.7 & 10520 & 32.1 & 1 & 0.0 \\
\hline $2000-$ & 5313 & 23.3 & 7753 & 23.6 & & \\
\hline \multicolumn{7}{|l|}{ Country of birth } \\
\hline Sweden & 19400 & 85.1 & 30341 & 92.5 & 29468 & 79.4 \\
\hline Other European countries & 1142 & 5.0 & 810 & 2.5 & 3394 & 9.1 \\
\hline Other & 2246 & 9.9 & 1665 & 5.1 & 4244 & 11.4 \\
\hline \multicolumn{7}{|l|}{ Number of offspring } \\
\hline 0 & 16971 & 74.5 & 25296 & 77.1 & 0 & \\
\hline 1 & 1586 & 7.0 & 2185 & 6.7 & 3807 & 10.3 \\
\hline 2 & 2455 & 10.8 & 3167 & 9.7 & 16194 & 43.6 \\
\hline $3+$ & 1776 & 7.8 & 2168 & 6.6 & 17105 & 46.1 \\
\hline \multicolumn{7}{|c|}{ Age at birth of first child (years) } \\
\hline$<25$ & 2483 & 10.9 & 3368 & 10.3 & 14068 & 37.9 \\
\hline $25-34$ & 2897 & 12.7 & 3707 & 11.3 & 20290 & 54.7 \\
\hline $35+$ & 437 & 1.9 & 445 & 1.4 & 2748 & 7.4 \\
\hline All & 22788 & 100.0 & 32816 & 100.0 & 37106 & 100.0 \\
\hline
\end{tabular}

Sweden, and around $25 \%$ of them had at least one offspring during the study period.

During the 484572 person-years of follow-up, the risks of lung $(\mathrm{SIR}=0.55)$, breast $(\mathrm{SIR}=0.79)$, and ovarian $(\mathrm{SIR}=0.61)$ cancers were statistically significantly decreased (Table 2). The risk of lung cancer was similar among men and women. In Table 3, we present the risk of lung, breast, and ovarian cancer among the siblings and parents of individuals with lactose intolerance. None of the cancer sites showed a significantly decreased or increased SIR.

\section{DISCUSSION}

In this population-based study, a total of 22788 individuals were identified with lactose intolerance between 1987 and 2010. This is, to our knowledge, the first study to examine the association between lactose intolerance and lung, breast, and ovarian cancers. The main finding was that the risks of lung, breast, and ovarian cancers were significantly decreased among individuals with lactose intolerance, whereas the incidences in their siblings and parents were similar compared with the general population.

The significantly decreased risk of lung, breast, and ovarian cancers in lactose-intolerant individuals suggests that these associations could be due to the low consumption of lactose or lactose-containing products. Caloric restriction has been found to be associated with a lower incidence of breast and ovarian cancers (Mao, 2004; Michels and Ekbom, 2004; Schouten et al, 2011; Zagouri et al, 2012). In addition, milk and other dairy products can contain high amounts of fats, particularly saturated fat, and some growth factors, such as insulin-like growth factor I (IGF-I), and these dietary components have been suggested to be associated 
Table 2. Cancer risk in patients with lactose intolerance by gender

\begin{tabular}{|c|c|c|c|c|c|c|c|c|c|c|c|c|}
\hline \multirow{3}{*}{ Lung } & \multicolumn{4}{|c|}{ Male } & \multicolumn{4}{|c|}{ Female } & \multicolumn{4}{|c|}{ All } \\
\hline & \multirow{2}{*}{$\begin{array}{l}\mathrm{O} \\
11\end{array}$} & \multirow{2}{*}{$\begin{array}{l}\text { SIR } \\
0.51\end{array}$} & \multicolumn{2}{|c|}{$95 \% \mathrm{Cl}$} & \multirow{2}{*}{$\begin{array}{l}\mathrm{O} \\
16\end{array}$} & \multirow{2}{*}{$\begin{array}{c}\text { SIR } \\
0.58\end{array}$} & \multicolumn{2}{|c|}{$95 \% \mathrm{Cl}$} & \multirow{2}{*}{$\begin{array}{l}\text { O } \\
27\end{array}$} & \multirow{2}{*}{$\begin{array}{l}\text { SIR } \\
0.55\end{array}$} & \multicolumn{2}{|c|}{$95 \% \mathrm{Cl}$} \\
\hline & & & 0.25 & 0.92 & & & 0.33 & 0.94 & & & 0.36 & 0.80 \\
\hline Breast & & & & & 118 & 0.79 & 0.65 & 0.94 & 118 & 0.79 & 0.65 & 0.94 \\
\hline Ovary & & & & & 16 & 0.61 & 0.35 & 0.99 & 16 & 0.61 & 0.35 & 0.99 \\
\hline All cancer & 235 & 0.95 & 0.84 & 1.08 & 499 & 0.96 & 0.88 & 1.05 & 734 & 0.96 & 0.89 & 1.03 \\
\hline
\end{tabular}

Table 3. Cancer risk among siblings and parents of patients with lactose intolerance

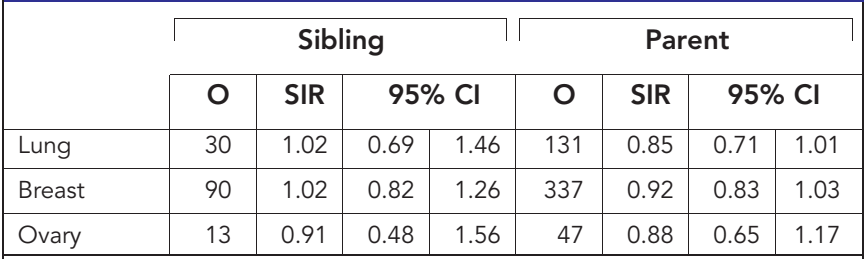

Abbreviations: $\mathrm{Cl}=$ confidence interval; $\mathrm{O}=$ observed number of cases; $\mathrm{SIR}=$ standardised incidence ratio.

with the development of various types of cancers ( $\mathrm{Yu}$ and Rohan, 2000; Goodwin et al, 2002; Stattin et al, 2004; Leosdottir et al, 2005; Gennigens et al, 2006). Insulin-like growth factor I can promote tumour cell growth through low apoptosis, high cell proliferation, and angiogenesis (Khandwala et al, 2000), and it was reported that high concentrations of IGF-I are associated with a greater risk of breast cancer (Renehan et al, 2004, 2006). Previous studies have found that high consumption of milk is associated with plasma IGF-I concentrations (Holmes et al, 2002; Morimoto et al, 2005), suggesting that low consumption of milk and other dairy products among individuals with lactose intolerance may be associated with a lower risk of breast cancer. Furthermore, avoidance of milk may alter the human gut microbiome, which may affect the development of tumours (David et al, 2014). However, we cannot exclude the protective effects on the development of cancers of other dietary patters, such as a consumption of plant milk (Ollberding et al, 2012; Wada et al, 2013), including soy and rice milks, which are often consumed by individuals with lactose intolerance. Moreover, whether the genetic variants found in lactose-intolerant individuals could confound the expression of other genes through linkage disequilibrium warrants investigation.

An important strength of this study is that all the data were retrieved from Swedish Registers with high quality and coverage. A recent review suggested that the diagnostic accuracy in Swedish Hospital Registers is high with a positive predictive value ranging between 85 and 95\% (Ludvigsson et al, 2011). In addition, the number of patients included is large enough to guarantee reliable risk estimates. The prospective study design and the completeness of the follow-up of patients are other major advantages of the present study. One limitation of this study is the lack of information on some individual-level risk factors, such as smoking, alcohol consumption, dietary habits, psychosocial factors, and sociocultural behaviours, as well as the lack of genetic or physiological testing on the diagnosis of lactose intolerance.

In summary, individuals with lactose intolerance had decreased risks of lung, breast, and ovarian cancers, which may be related to their specific dietary patterns, but the contributions from other confounding factors should not be neglected.

\section{ACKNOWLEDGEMENTS}

We thank the CPF's Science Editor Stephen Gilliver for his valuable comments on the text. This work was supported by grants to Dr Kristina Sundquist from the Swedish Research Council (K2009-70X-15428-05-3; K2012-70X-15428-08-3), as well as ALF funding from Region Skåne awarded to Jan Sundquist, Kristina Sundquist, and Dr Jianguang Ji. The funding agencies had no role in the design and conduct of the study; in the collection, analysis, and interpretation of the data; or in the preparation, review, or approval of the manuscript. The researchers were independent of the funding agencies. This study was approved by the Regional Ethical Review Board of Lund University in Sweden.

\section{CONFLICT OF INTEREST}

The authors declare no conflict of interest.

\section{AUTHOR CONTRIBUTIONS}

JJ, KS, and JS were responsible for the study concept and design. JS obtained funding. KS and JS acquired the data. JJ analysed and interpreted the data. JJ did the statistical analysis. JJ drafted the manuscript, and all authors revised it for important intellectual content. JS is the guarantor.

\section{REFERENCES}

Axelsson G, Rylander R (2002) Diet as risk for lung cancer: a Swedish case-control study. Nutr Cancer 44(2): 145-151.

Boyd NF, Martin LJ, Noffel M, Lockwood GA, Trichler DL (1993) A metaanalysis of studies of dietary fat and breast cancer risk. Br J Cancer 68(3): 627-636.

Breslow NE, Day NE (1987) Statistical methods in cancer research. Volume 2-The design and analysis of cohort studies. IARC Sci Publ 2: 1-406.

Cramer DW (1989) Lactase persistence and milk consumption as determinants of ovarian cancer risk. Am J Epidemiol 130(5): 904-910.

David LA, Maurice CF, Carmody RN, Gootenberg DB, Button JE, Wolfe BE, Ling AV, Devlin AS, Varma Y, Fischbach MA, Biddinger SB, Dutton RJ, Turnbaugh PJ (2014) Diet rapidly and reproducibly alters the human gut microbiome. Nature 505(7484): 559-563.

Dong JY, Zhang L, He K, Qin LQ (2011) Dairy consumption and risk of breast cancer: a meta-analysis of prospective cohort studies. Breast Cancer Res Treat 127(1): 23-31.

Ekbom A (2011) The Swedish Multi-generation Register. Methods Mol Biol 675: 215-220.

Enattah NS, Sahi T, Savilahti E, Terwilliger JD, Peltonen L, Jarvela I (2002) Identification of a variant associated with adult-type hypolactasia. Nature Genet 30(2): 233-237.

Esteve J, Benhamou E, Raymond L (1994) Statistical methods in cancer research. IARC: Lyon, France. 
Genkinger JM, Hunter DJ, Spiegelman D, Anderson KE, Arslan A, Beeson WL, Buring JE, Fraser GE, Freudenheim JL, Goldbohm RA, Hankinson SE, Jacobs Jr. DR, Koushik A, Lacey Jr JV, Larsson SC, Leitzmann M, McCullough ML, Miller AB, Rodriguez C, Rohan TE, Schouten LJ, Shore R, Smit E, Wolk A, Zhang SM, Smith-Warner SA (2006) Dairy products and ovarian cancer: a pooled analysis of 12 cohort studies. Cancer Epidemiol Biomarkers Prev 15(2): 364-372.

Gennigens C, Menetrier-Caux C, Droz JP (2006) Insulin-Like Growth Factor (IGF) family and prostate cancer. Crit Rev Oncol Hematol 58(2): 124-145.

Goodwin PJ, Ennis M, Pritchard KI, Trudeau ME, Koo J, Hartwick W, Hoffma B, Hood N (2002) Insulin-like growth factor binding proteins 1 and 3 and breast cancer outcomes. Breast Cancer Res Treat 74(1): 65-76.

Holmes MD, Pollak MN, Willett WC, Hankinson SE (2002) Dietary correlates of plasma insulin-like growth factor I and insulin-like growth factor binding protein 3 concentrations. Cancer Epidemiol Biomarkers Prev 11(9): 852-861.

Ji J, Hemminki K (2007) Risk for contralateral breast cancers in a population covered by mammography: effects of family history, age at diagnosis and histology. Breast Cancer Res Treat 105(2): 229-236.

Khandwala HM, McCutcheon IE, Flyvbjerg A, Friend KE (2000) The effects of insulin-like growth factors on tumorigenesis and neoplastic growth. Endocr Rev 21(3): 215-244.

Kubik AK, Zatloukal P, Tomasek L, Pauk N, Havel L, Krepela E, Petruzelka L (2004) Dietary habits and lung cancer risk among non-smoking women. Eur J Cancer Pre 13(6): 471-480.

Larsson SC, Bergkvist L, Wolk A (2004) Milk and lactose intakes and ovarian cancer risk in the Swedish Mammography Cohort. Am J Clin Nutr 80(5): $1353-1357$.

Larsson SC, Orsini N, Wolk A (2006) Milk, milk products and lactose intake and ovarian cancer risk: a meta-analysis of epidemiological studies. Int J Cancer 118(2): 431-441.

Leosdottir M, Nilsson PM, Nilsson JA, Mansson H, Berglund G (2005) Dietary fat intake and early mortality patterns-data from The Malmo Diet and Cancer Study. J Intern Med 258(2): 153-165.

Ludvigsson JF, Andersson E, Ekbom A, Feychting M, Kim JL, Reuterwall C, Heurgren M, Olausson PO (2011) External review and validation of the Swedish national inpatient register. BMC Public Health 11: 450.

Mao JJ (2004) Risks and benefits of severe caloric restriction. JAMA 291(22): 2704.

Michels KB, Ekbom A (2004) Caloric restriction and incidence of breast cancer. JAMA 291(10): 1226-1230.

Missmer SA, Smith-Warner SA, Spiegelman D, Yaun SS, Adami HO, Beeson WL, van den Brandt PA, Fraser GE, Freudenheim JL, Goldbohm RA, Graham S, Kushi LH, Miller AB, Potter JD, Rohan TE, Speizer FE, Toniolo P, Willett WC, Wolk A, Zeleniuch-Jacquotte A, Hunter DJ (2002) Meat and dairy food consumption and breast cancer: a pooled analysis of cohort studies. Int J Epidemiol 31(1): 78-85.

Moorman PG, Terry PD (2004) Consumption of dairy products and the risk of breast cancer: a review of the literature. Am J Clin Nutr 80(1): 5-14.
Morimoto LM, Newcomb PA, White E, Bigler J, Potter JD (2005) Variation in plasma insulin-like growth factor-1 and insulin-like growth factor binding protein-3: personal and lifestyle factors (United States). Cancer Causes Control 16(8): 917-927.

Ollberding NJ, Lim U, Wilkens LR, Setiawan VW, Shvetsov YB, Henderson BE, Kolonel LN, Goodman MT (2012) Legume, soy, tofu, and isoflavone intake and endometrial cancer risk in postmenopausal women in the multiethnic cohort study. J Natl Cancer Inst 104(1): 67-76.

Qi L (2009) Mendelian randomization in nutritional epidemiology. Nutr Rev 67(8): 439-450.

Renehan AG, Harvie M, Howell A (2006) Insulin-like growth factor (IGF)-I, IGF binding protein-3, and breast cancer risk: eight years on. Endocrine Relat Cancer 13(2): 273-278.

Renehan AG, Zwahlen M, Minder C, O’Dwyer ST, Shalet SM, Egger M (2004) Insulin-like growth factor (IGF)-I, IGF binding protein-3, and cancer risk: systematic review and meta-regression analysis. Lancet 363(9418): 1346-1353.

Rothman KJ, Greenland S (eds) (1998) Modern epidemiology 2, LippincottRaven Publishers: Philadelphia, PA, USA.

Sahi T (1994) Genetics and epidemiology of adult-type hypolactasia. Scand J Gastroenterol Suppl 202: 7-20.

Schouten LJ, van Dijk BA, Lumey LH, Goldbohm RA, van den Brandt PA (2011) Energy restriction during childhood and early adulthood and ovarian cancer risk. PloS One 6(11): e27960.

Stattin P, Rinaldi S, Biessy C, Stenman UH, Hallmans G, Kaaks R (2004) High levels of circulating insulin-like growth factor-I increase prostate cancer risk: a prospective study in a population-based nonscreened cohort. J Clin Oncol 22(15): 3104-3112.

van der Pols JC, Bain C, Gunnell D, Smith GD, Frobisher C, Martin RM (2007) Childhood dairy intake and adult cancer risk: 65-y follow-up of the Boyd Orr cohort. Am J Clin Nutr 86(6): 1722-1729.

Vesa TH, Marteau P, Korpela R (2000) Lactose intolerance. J Am Coll Nutr 19(2 Suppl): 165S-175S.

Wada K, Nakamura K, Tamai Y, Tsuji M, Kawachi T, Hori A, Takeyama N, Tanabashi S, Matsushita S, Tokimitsu N, Nagata C (2013) Soy isoflavone intake and breast cancer risk in Japan: from the Takayama study. Int $J$ Cancer 133: 952-960.

Wilt TJ, Shaukat A, Shamliyan T, Taylor BC, MacDonald R, Tacklind J, Rutks I, Schwarzenberg SJ, Kane RL, Levitt M (2010) Lactose intolerance and health. Evid Rep Technol Assess 192: 1-410.

World Cancer Research Fund PA (2007) Food, nutrition, physical activity and the prevention of cancer: a global perspectiveAmerican Institute for Cancer Research: Washington, DC, USA.

Yu H, Rohan T (2000) Role of the insulin-like growth factor family in cancer development and progression. J Natl Cancer Inst 92(18): 1472-1489.

Zagouri F, Dimitrakakis C, Dimopoulos MA, Tsigginou A, Antsaklis A, Papadimitriou CA (2012) A woman with breast cancer and severe impaired lactose tolerance: an intriguing therapeutic dilemma. Breast J 18(6): 628-629. 